\title{
Efficient heating of piglet nests
}

\begin{abstract}
Summary
The impact of hovers (closed nests) in the farrowing pen on energy consumption was studied. The hovers were equipped with electric heating tube, sensor, and automatically controlled heat regulation. They reduce energy losses and provide a warm environment for piglets, as well as a thermally suitable farrowing unit for sows. Temperature wise, hovers provide a high level of comfort for both. During the two-year experimental period, electricity usage was measured from farrowing to weaning during 60 lactations standardised to 28 days. On average, the electricity consumption was $42.68 \mathrm{kWh}$ per lactation $(51.51 \mathrm{kWh}$ in winter and $33.65 \mathrm{kWh}$ during summer season). Major part of the energy was used in the first week of lactation (41.45\%). After that, the weekly usage of energy decreased $(29.26 \%, 19.89 \%, 9.40 \%$ from the second to the fourth week, respectively) because of the decreased needs for supplemental heating and increased self produced warmth of older piglets. The calculation of total costs for heating showed that nearly 100.21 EUR per farrowing pen were saved annually compared to the system without hovers and without heat regulation, a common practice in piglet production.
\end{abstract}

Key Words: piglets, hovers, heating, costs

\section{Zusammenfassung}

\section{Titel der Arbeit: Wirtschaftliche Heizung der Ferkelnester}

Der Einfluss von geschlossenen Ferkelkisten auf den Stromverbrauch in Abferkelbuchten wurde untersucht. Ferkelkisten wurden mit einem Elektroheizrohr, Wärmefühler und automatischer Temperaturregelung ausgerüstet. Die geschlossene Ferkelkiste reduziert den Wärmeverlust durch Konvektion und ermöglicht eine ferkelgemäße warme Umwelt in der Kiste. Im Abferkelstall kann aber eine niedrigere, sauengemäße Temperatur sein. In einem zweijährigen Versuch wurde bei 60 Würfen der Stromverbrauch vom Abferkeln bis zum Absetzen am 28. Tag gemessen. Der durchschnittliche Stromverbrauch betrug 42,68 kWh pro Wurf $(51,51 \mathrm{kWh}$ im Winter und $33,65 \mathrm{kWh}$ im Sommer). Der größte Stromverbrauch war in der ersten Laktationswoche $(41,45 \%)$ festzustellen, später wurde dieser immer geringer. Von der zweiten bis zur vierten Woche betrug er nur noch 29,26\%, 19,89 und 9,40 \%, verursacht durch immer geringeren Wärmebedarf und größere Wärmeabgabe älterer Ferkel. Die Kostenkalkulation zeigte, dass das System geschlossener Kisten 100,21 EUR weniger Kosten pro Jahr und Abferkelbucht für die Heizung der Ferkelnester, als das klassische System mit Infrarotlampen ohne Wärmeregulation benötigte.

Schlüsselwörter: Ferkel, Ferkelkiste, Heizung, Kosten

\section{Introduction}

In the farrowing house, sows and piglets have very different thermal requirements. Adequate temperature for sows is much below the lower critical temperature for piglets, whereas adequate temperature for piglets is much above the upper critical temperature for sows (BAXTER, 1984; MAKKINK and SCHRAMA, 1998). If the temperature in the farrowing house is high and comfortable for piglets, the sows suffer heat stress. Therefore, they consume less food (JACOBSON and JOHNSTON, 1994), produce less milk, and because of this, piglets have lower daily gains. Lower temperature in the farrowing house is comfortable for sows, but then it is necessary to warm piglet nests. In the classical warming system with infrared bulbs, the warm air 
rises, because of convection, under the ceiling of the stall, and the cold air enters piglets nest from the sides. Piglets try to escape the cold air and tend to move towards the middle of the nest. These movements cause permanent restlessness of piglets. Beside heat, the bulbs produce undesirable bright light (MAKKINK and SHRAMA, 1998), which is unpleasant for piglets. Electric heating tube with thermostats can replace the bulbs. Air convection and heat loss from the nest are prevented in closed nests, named also hovers.

The advantages of closed nests are reviewed by different authors (RIST, 1989; MAKKINK and SCHRAMA, 1998). While piglets are lying 43\% longer in the nest than close to the sow, the losses of suckling piglets are thus reduced. Ambient temperature for piglets changes frequently, which stimulates piglets to develop thermoregulation mechanism at an earlier stage. When they are suckling, they are exposed to low temperature, have higher milk intake, and return faster back to the hover. Additional heating is reduced to small covered area even in cold weather. Cooler ambient is more suitable for the sow. She is resting in relaxed position, has larger feed intake, and thus increased milk production. In other words, optimal temperature is important for maximal performance, better health status, and animal welfare, as indicated by GEERS and GOEDSEELS (1993). It is important to achieve more convenient environmental temperature for a sow and her piglets at the same time. The energy need for thermal comfort of piglets is gradually reducing with age and body weight due to developing thermoregulation as well as larger heat production with increased body size. In the hover equipped with thermostat, more efficient use of electrical energy can be achieved by the regulation of temperature in the nest (WEBER, 1987). The necessary nest heating also depends on ambient temperature, temperature of incoming air, type of floor, presence of bedding, amount of insulation in the floor, walls and ceiling, as well as the number of pigs in a group (WEBER, 1984; RIST, 1989). These factors influence the energy usage, and temperature perception in piglets. Lower energy usage is also an important contribution to environmental protection.

The aim of this paper was to determine the effect of different temperatures, as well as piglets weight and age on energy usage in hovers. At the end of the trial period, we calculated cost difference per pen and year between the closed and open nests.

\section{Material and methods}

The experiment lasted two years, from July 1994 to August 1996 on a family farm. In the stall, there were eleven farrowing pens $(190 \times 210 \mathrm{~cm})$ with partially slatted floor, wooden fences, horizontal cradles. Sow feeders $(60 \times 40 \mathrm{~cm})$ and nipple drinkers were placed in front, while piglet feeders $(70 \times 22 \mathrm{~cm})$ and bowls with warmed water at the side of the pen. Sows were fed ad libitum with complete diet. Pre-starter feed was offered to the piglets after the first week.

The hovers were placed in the front corner of farrowing pens to allow the breeder as well as the sow to control the piglets. The floor in the nest $(60 \times 120 \mathrm{~cm})$ was concrete and bedded with straw. Full, wooden fences of the pens created the nest backs. The hover (Fig. 1) had wooden cover $60 \mathrm{~cm}$ high and plastic curtains on the side that allowed free piglet movement and inspection of the litter. The nest cover had a vent for air exchange, which was occasionally opened, mainly during the last week of lactation in summer. The electric heating tube $(200 \mathrm{~W})$ was placed $30 \mathrm{~cm}$ above the nest floor 
on day 1, $40 \mathrm{~cm}$ on day 2 to 14 , and $50 \mathrm{~cm}$ on day 15 to 28 . Heating was regulated automatically by sensor with thermostat, which was set manually according to the piglets' behaviour (BOON, 1981; GEERS et al., 1986). While piglets were lying in relaxed postures at adequate temperature, they were spread all over the pen when overheated, and crowded together in the middle of the nest at lower temperature. The piglets' behaviour was inspected at least five times per day. In order to measure the usage of electricity, each hover was equipped with an electric counter. Hovers were homemade. Besides the components mentioned above, the breeder used PVC regulation box, metal tube with a screw for height regulation, metal heater shield, and wooden cover.

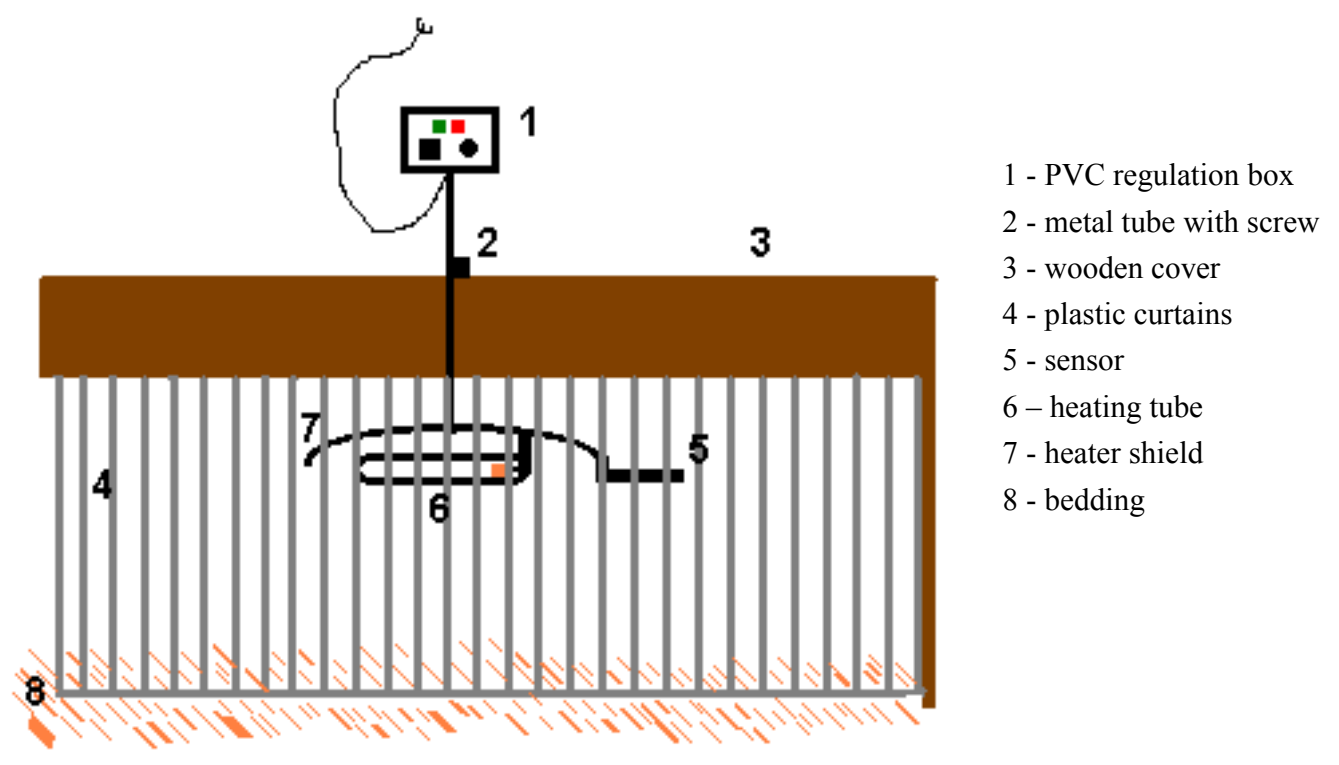

Fig. 1: Cross section of the hover (Querschnitt der Ferkelkiste)

Usage of electricity was measured in 60 litters from birth to weaning. Lactations were standardized to 28 days. The day when a sow farrowed was skipped from evaluation because the energy usage depends on the time of farrowing. Piglets were counted and weighed at birth, on the day 8, 22, and at weaning. Piglet losses were recorded at birth as well as during lactation. The indoor and outdoor temperature was measured on the farm once per day, at 2 p.m. Temperatures were used as explanatory variables. Average daily temperatures from the nearest weather station were acquired, too. In preliminary analyses, this temperature did not show significant effect and was excluded. Data was analyzed by SAS/STAT (SAS, 2000). Analysis of variance was done using the least square method in the general linear procedure (GLM). Daily usage of electricity $\left(\mathrm{y}_{\mathrm{ijk}}\right)$ was analysed by the following statistical model:

$$
y_{i j k}=\mu+L_{i}+T_{j}+b_{1 i}\left(t_{i j k}-\bar{t}\right)+b_{2 i}\left(t_{i j k}-\bar{t}\right)^{2}+b_{3 j}\left(x_{i j k}-\bar{x}\right)+b_{4 j}\left(z_{i j k}-\bar{z}\right)+b_{5 j}\left(w_{i j k}-\bar{w}\right)+e_{i j k}
$$

The model contained two fixed effects: season $\left(\mathrm{L}_{\mathrm{i}}\right.$ as spring, summer, fall, and winter) and lactation interval $\left(\mathrm{T}_{\mathrm{j}}\right.$ as $1^{\text {st }}$ week, $2^{\text {nd }}-3^{\text {rd }}$ week and $4^{\text {th }}$ week). The day of lactation $\left(\mathrm{t}_{\mathrm{ijk}}\right)$ was fitted as second order polynomial within season, while the average indoor $\left(\mathrm{x}_{\mathrm{ijk}}\right)$ and outdoor $\left(\mathrm{z}_{\mathrm{ijk}}\right)$ temperature, as well as average live weight per piglet $\left(\mathrm{w}_{\mathrm{ijk}}\right)$ were included in the model as linear regression within lactation interval. Residuals 
$\left(\mathrm{e}_{\mathrm{ijk}}\right)$ were assumed to be normally and independently distributed. Heteroscedasticity was tested for all covariates. Null hypotheses shown below were tested against alternatives where heteroscedasticity was assumed.

$$
\begin{aligned}
H_{0}: b_{11}=b_{12}=b_{13}=b_{14}=b_{1} & H_{0}: b_{31}=b_{32}=b_{33}=b_{3} \\
b_{21}=b_{22}=b_{23}=b_{24}=b_{2} & H_{0}: b_{41}=b_{42}=b_{43}=b_{4} \\
& H_{0}: b_{51}=b_{52}=b_{53}=b_{5}
\end{aligned}
$$

Finally, the costs of nest heating were calculated according to the De Baey-Ernsten method (DE BAEY-ERNSTEN et al., 1996) for the open and closed nests. The electricity usage in open nests was estimated from the bulb power and time of heating. It was assumed that a $250 \mathrm{~W}$ bulb had been used for four weeks 24 hours per day as is still often used in practice.

\section{Results}

The outdoor temperature changed with season (Fig. 2). The average value was $15.7^{\circ} \mathrm{C}$. The lowest value was obtained in winter $\left(-4.4^{\circ} \mathrm{C}\right)$ and the highest in summer $\left(33.5^{\circ} \mathrm{C}\right)$, as expected. The average indoor temperature was slightly higher $\left(18.2^{\circ} \mathrm{C}\right)$. It was less variable and did not change much with season. The indoor temperature was stabile during fall, winter, and spring due to good insulation of the building, while in summer, it followed the rise of outdoor temperature. The lowest indoor temperature was $15.1^{\circ} \mathrm{C}$ in winter and $15.9^{\circ} \mathrm{C}$ in summer, while the maximum value differed about $5^{\circ} \mathrm{C}$ between winter $\left(20.3^{\circ} \mathrm{C}\right)$ and summer $\left(25.1^{\circ} \mathrm{C}\right)$.

On average, there were 10.53 piglets born alive (Table 1) with weight $1.48 \mathrm{~kg}$ per piglet. Losses during lactation were small $(2.47 \%)$. Litter at weaning counted 10.27 piglets with weaning weight $6.69 \mathrm{~kg}$.

Electricity usage per lactation was $42.68 \mathrm{kWh}$ on the average. It was higher in winter $(51.51 \mathrm{kWh})$, lower in summer $(33.65 \mathrm{kWh})$, and intermediate during spring $(42.89 \mathrm{kWh})$ and fall $(45.61 \mathrm{kWh})$. Major part of the energy was used in the first week of lactation (41.45\%). After that, the weekly usage of energy decreased by $29.26 \%$, $19.89 \%, 9.40 \%$ from the second to the fourth week, respectively.

Table 1

The litter size and litter weight during lactation (Wurfgrösse und Wurfgewicht während der Laktation)

\begin{tabular}{lccc}
\hline \multicolumn{1}{c}{ Weighing } & $\begin{array}{c}\text { Avg. number of piglets in } \\
\text { litter }\end{array}$ & $\begin{array}{c}\text { Avg. live weight of litter } \\
(\mathrm{kg})\end{array}$ & $\begin{array}{c}\text { Avg. live weight of piglet } \\
(\mathrm{kg})\end{array}$ \\
\hline At birth & 10.53 & 15.55 & 1.48 \\
Day 8 & 10.32 & 31.12 & 3.02 \\
Day 22 & 10.28 & 54.66 & 5.33 \\
At weaning & 10.27 & 68.45 & 6.69 \\
\hline
\end{tabular}

All effects in the model were significant with P-value below 0.0001. Energy usage was decreasing significantly over lactation (Table 2, Fig. 3), as expected. Decrease was not only linear; the quadratic term was also significant. Test for heteroscedasticity proved that curves differed among seasons $(\mathrm{P}<0.0001)$. The estimated curves are additionally illustrated in Fig. 4. When compared to measurements (Fig. 3), we realised that the difference between summer and winter at the beginning of lactation disappeared. 


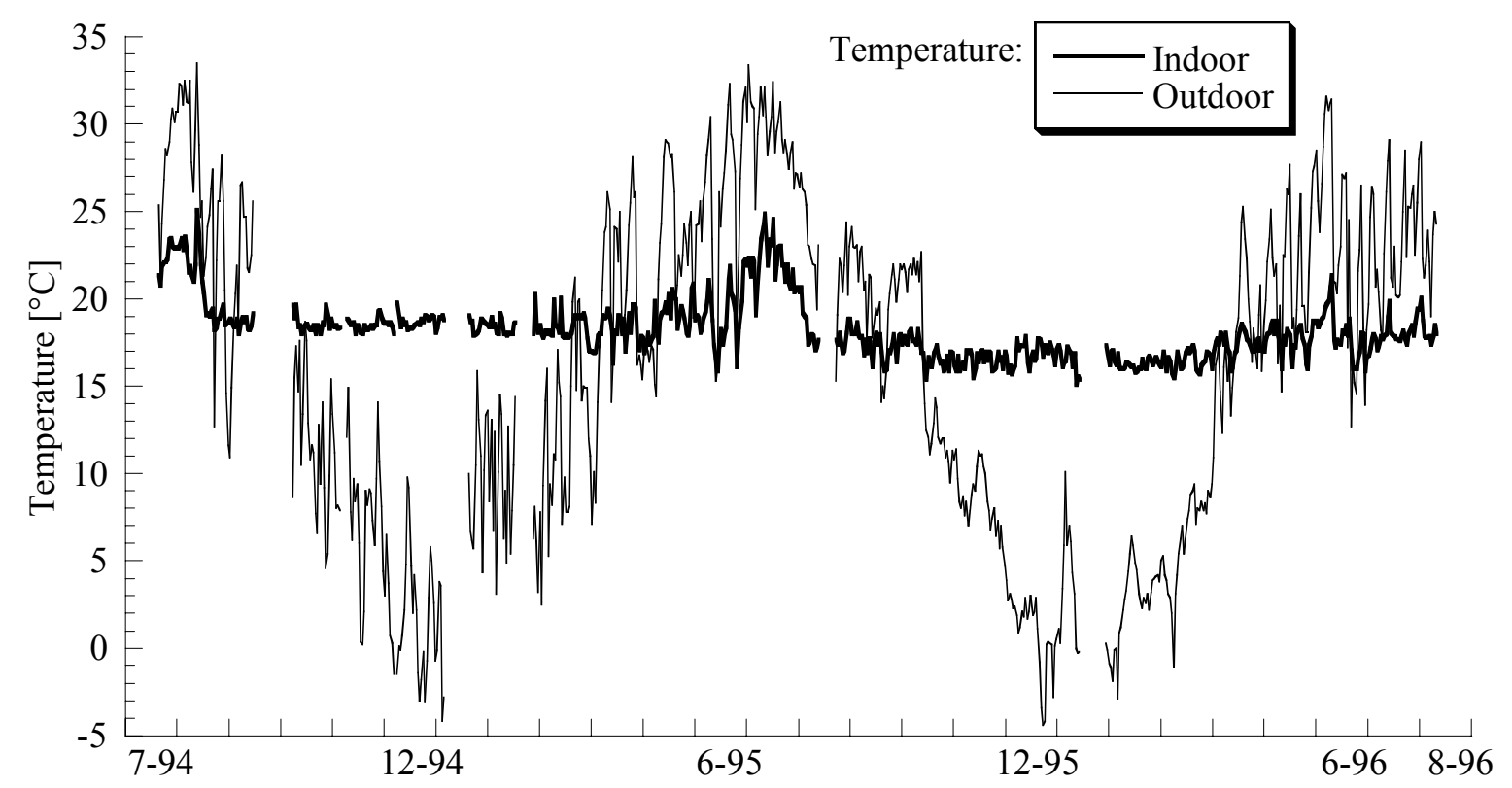

Fig. 2: Indoor and outdoor air temperature during experiment (Innen- und Aussentemperatur während des Versuches)

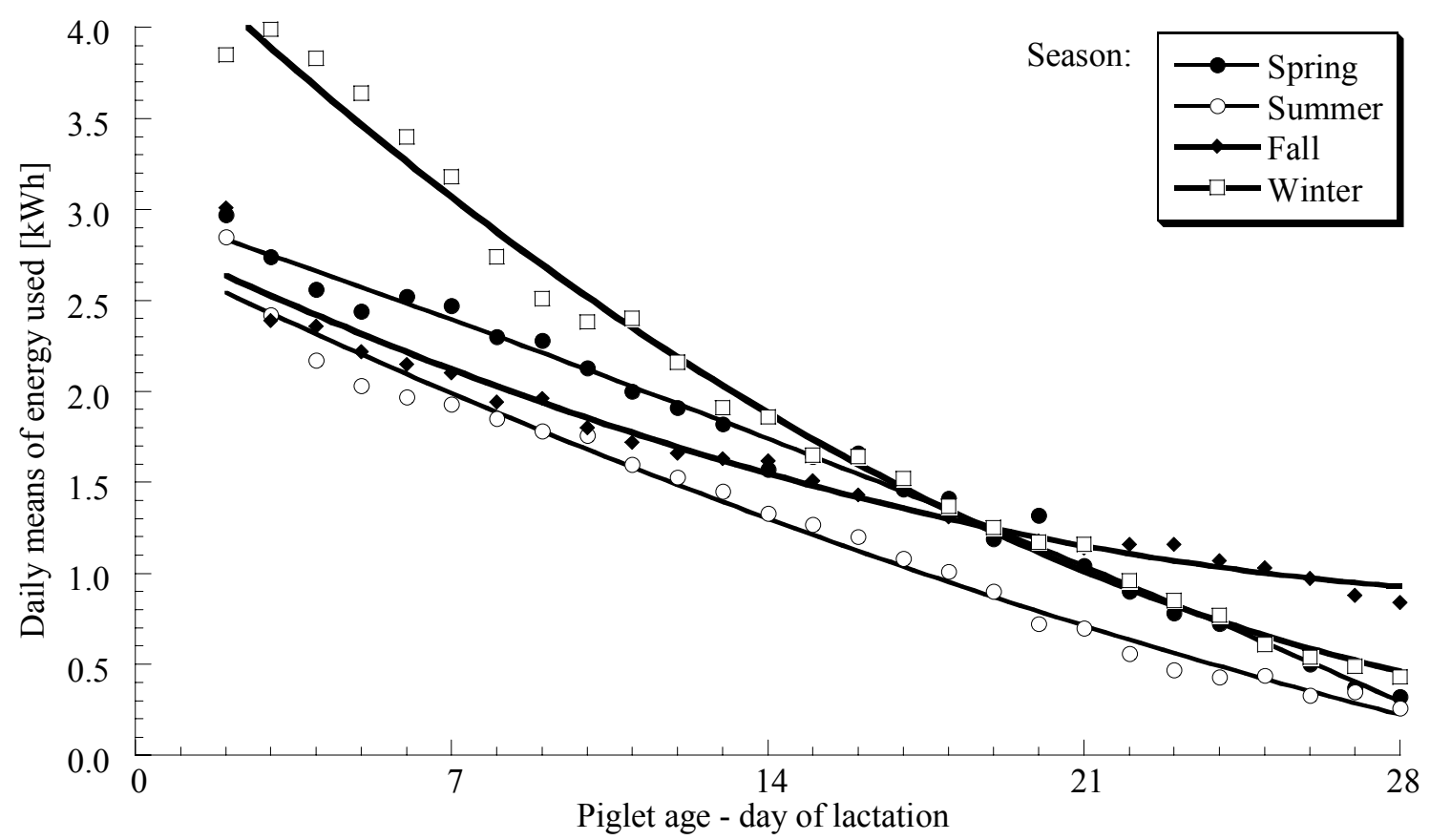

Fig. 3: Daily amount of energy used in hover during lactation (Täglicher Energieverbrauch in Ferkelkisten während der Laktation)

Table 2

Regression coefficients for day of lactation within season (Korrelationskoeffizienten für den Laktationstag innerhalb der Saison)

\begin{tabular}{lccc}
\hline & & \multicolumn{2}{c}{ Estimated regression coefficient \pm SEE } \\
Season & Estimated season on day $15 \pm$ SEE & Linear & Quadratic \\
\hline Spring & $1.6405 \pm 0.0328$ & $-0.0948 \pm 0.0041$ & $-0.00078 \pm 0.00049$ \\
Summer & $1.5484 \pm 0.0401$ & $-0.1050 \pm 0.0046$ & $0.00217 \pm 0.00055$ \\
Fall & $1.2642 \pm 0.0379$ & $-0.0577 \pm 0.0047$ & $0.00219 \pm 0.00058$ \\
Winter & $1.3453 \pm 0.0492$ & $-0.1190 \pm 0.0060$ & $0.00229 \pm 0.00070$ \\
\hline SEE - standard error of estimate & &
\end{tabular}

SEE - standard error of estimate 


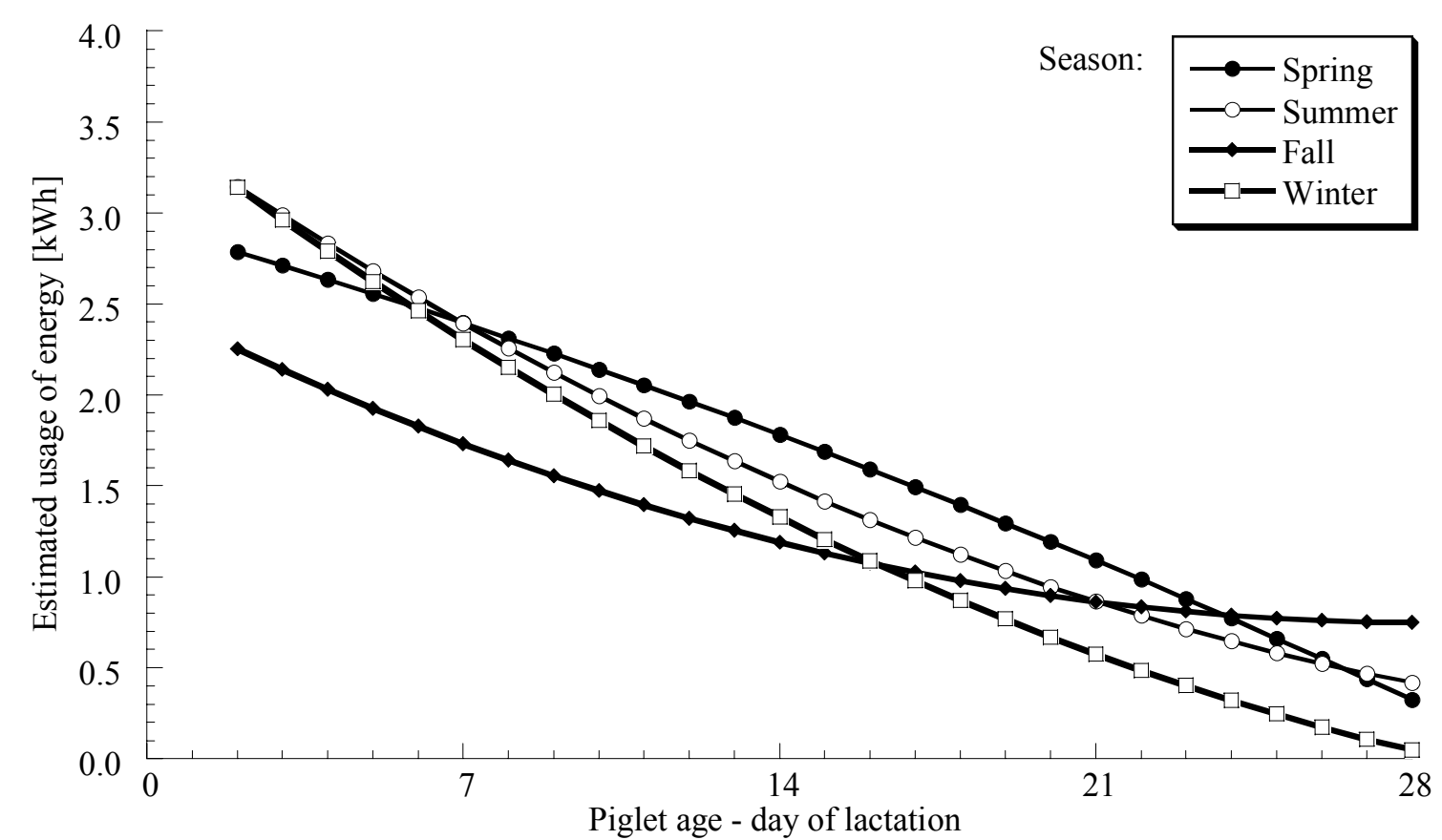

Fig. 4: Estimated changes for daily amount of energy in hover during lactation (Geschätzte Veränderungen des täglichen Energieverbrauches in Ferkelkisten während der Laktation)

The indoor and outdoor temperature had significant effect $(\mathrm{P}<0.0001)$. Test for heteroscedasticity demonstrated that slope of linear regression differed among lactation intervals. The higher the temperature inside and/or outside the barn, the lower the amount of energy used for heating. In general, the change of indoor temperature for $1{ }^{\circ} \mathrm{C}$ induced larger savings than the outdoor. However, the range of outdoor temperature was much wider comparing to indoor temperature, causing important contribution to lower energy usage.

Table 3

Regression coefficients for indoor and outdoor temperature, and live weight of piglet within lactation interval (Regressionskoeffizienten für die Innen- und Außentemperatur und das Lebensgewicht der Ferkel während der Laktation)

\begin{tabular}{llcc}
\hline Covariate & Lactation interval & Regression coefficient \pm SEE & P - value \\
\hline Indoor temperature & 1st week & $-0.1859 \pm 0.0190$ & $<.0001$ \\
& 2nd and 3rd week & $-0.1195 \pm 0.0129$ & $<.0001$ \\
& 4th week & $0.0100 \pm 0.0209$ & 0.6318 \\
& & & $<.0001$ \\
Outdoor temperature & 1st week & $-0.0505 \pm 0.0045$ & $<.0001$ \\
& 2nd and 3rd week & $-0.0252 \pm 0.0030$ & $<.0001$ \\
& 4th week & $-0.0283 \pm 0.0043$ & $<.0001$ \\
Live weight of piglet at the & 1st week & & $<.0001$ \\
beginning of interval & 2nd and 3rd week & $-0.3304 \pm 0.0682$ & 0.1568 \\
\hline
\end{tabular}

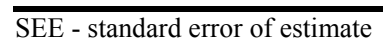

Indoor temperature caused reduction of energy usage by the rate of $-0.1859 \mathrm{kWh} /{ }^{\circ} \mathrm{C}$ in the first week of lactation. Reduction was smaller $\left(-0.1195 \mathrm{kWh} /{ }^{\circ} \mathrm{C}\right)$ at the middle interval. At the end of lactation, temperature inside the barn did not have significant 
effect any more (Table 3). Differences among intervals were expected due to improved thermoregulation in growing piglets.

The same trend was observed for outdoor temperature, as well. The only deviation was on the last interval where saving was significant and even slightly higher than on the second interval. The outdoor temperature, or the difference between outdoor and indoor temperature affects the ventilation, air movement and wall temperature and thus, affects piglet behavior.

If the average starting weight of piglet was higher at the same stage of lactation, significant saving of energy was recorded $(\mathrm{P}<0.0001)$. The trend can be clarified because the heavier piglets at the same age had better heat production and better thermoregulation, as well.

Table 4

Annual costs in EUR for nest warming per pen in 28-day lactation (Jahreskosten in EUR für die Heizung der Ferkelnester bei 28-tägiger Laktation pro Abferkelbucht)

\begin{tabular}{|c|c|c|c|c|}
\hline Symbol & Costs & Calculation & Hover & $\begin{array}{l}\text { Open nest with } \\
250 \mathrm{~W} \text { infra bulb }\end{array}$ \\
\hline $\mathrm{S} 1$ & Investment costs (EUR) & & 107.62 & 21.74 \\
\hline $\mathrm{S} 2$ & Amortisation (EUR) & $10 \%$ of $\mathrm{S} 1$ & 10.76 & 2.17 \\
\hline $\mathrm{S} 3$ & Maintenance costs (EUR) & & 0 & 18.57 \\
\hline $\mathrm{S} 4$ & Technological costs (EUR) & $\mathrm{S} 2+\mathrm{S} 3$ & 10.76 & 20.74 \\
\hline S5 & Electricity usage per lactation $(\mathrm{kWh})$ & & 42.68 & 168.00 \\
\hline S6 & Farrowings per year & & 10 & 10 \\
\hline S7 & Price per $1 \mathrm{kWh}$ (EUR) & & 0.072 & 0.072 \\
\hline S8 & Effectiveness * & & 1 & 1 \\
\hline S9 & Energy costs (EUR) & $\mathrm{S} 5 \times \mathrm{S} 6 \times \mathrm{S} 7 / \mathrm{S} 8$ & 30.73 & 120.96 \\
\hline S10 & Total costs (EUR) & $\mathrm{S} 4+\mathrm{S} 9$ & 41.49 & 141.70 \\
\hline
\end{tabular}

* Effectiveness 1 means, that there were no losses in energy transmission

The annual energy costs per farrowing pen in a closed nest with a heating tube regulated by a thermostat was compared to the open nest where we assumed heating with 250-W infrared bulb during the whole lactation (Table 4), which is still the most commonly used heating system in our herds. Calculation was done for a 28-day lactation. The lifetime of equipment was assumed to be ten years. Total annual costs in open nests (141.70 EUR) were 3.4-times higher than the annual costs in hovers (41.49 EUR).

\section{Discussion}

A hover was designed in order to increase sow and piglet welfare and to decrease energy costs. The homemade hovers replaced heating bulbs on the farm. Comparison of energy usage could be done because the bulbs in the old system were used all the time during lactation and the energy usage could be calculated from the bulb power and time. Total costs were reduced to $30 \%$. Almost $90 \%$ of cost difference was contributed by the reduction of energy costs in hovers to a quarter. The reduction of energy usage is possible also by the change of bulbs with different power and can be efficient depending on the schedule (VOGRIN-BRAČIC substantial with hovers due to gradual reduction of energy usage and lower maintenance costs. 
The average usage of energy decreased as lactation progressed (Fig. 3). With piglet growth, needs for warmth decreased rapidly. Energy use in the third week was approximately only half of the quantity used in the first week. In the last week, needs were further reduced by half. Even more, the reduction was steady over lactation in all seasons, higher in winter and lower in fall.

Because the model contained indoor and outdoor temperature, the important part of seasonal effect was eliminated. The lower amounts used in spring and especially in the fall, as well as the differences in the second part of lactation were more difficult to explain from the data. The possible reason might be that behaviour of piglets or even the action of breeder was influenced by the perception of the environmental temperature. The degree of comfort in response to a given air temperature is influenced by air movement, air humidity, type of floor, amount of insulation in the floor, walls and ceiling, as well as the number of pigs in a group and the amount of feed intake. All these variables are considered in the term effective environmental temperature (BRUMM and REESE, 1992). In the fall, energy usage was decreasing slower and stayed higher at the end of lactation, compared to other seasons. The fall had a completely different curve compared to other seasons. Changes were almost the same before (Fig. 3) and after (Fig. 4) the adjustments for temperature effects. This might be the proof that development of thermoregulation mechanism in piglets was slowest in the fall. It was also the only season where the environmental temperature decreased with piglet age.

The difference is also in investment and maintenance costs. Investment costs were almost five times higher for hover than for the open nest. The hovers have been used for eight years with no maintenance needs. However, maintenance costs were higher for open nests mainly due to the short lifetime of bulbs. It is clear, that hovers should be preferred from the animal welfare and breeder point of view. ENGLISH et al. (1982) had drawn similar conclusions. They expected that heating the hover could reduce the amount of energy by two to three times. Because of increased costs of energy, our results were expected.

ENGLISH et al. (1982) also listed and explained other benefits like reduced losses and welfare of piglets. The same was established later by RIST (1989). The breeder obtained good fertility compared to other family-farms recorded in the same period (KOVAC , 1997). It cannot be confirmed that they were due to hover use. However, piglet losses during lactation and litter size at weaning showed that the environment was comfortable for the piglets.

The decision for the breeder to use hovers would not be difficult if based not only on investment, but also on maintenance and animal performance.

\section{Acknowledgement}

We wish to acknowledge to Mrs. Marija Vogrin-Bračič, BSc and her family who enabled and carried out the experiment on their farm. We are grateful to Mrs. Karmela Malinger for proof reading the manuscript.

\section{References}

DE BAEY-ERNSTEN, H.; BICHMAN, M.; HAAR, F.; CLAUSEN, N.:

Wie kommt die Wärme kostengünstig ans Ferkel? Schweinezucht und Schweinemast, Münster 44 (1996), 36-38 
BAXTER, S.:

Intensive Pig Production. Environmental management and design. Granada Publishing, London. 1984, $55-78$

BOON, C.R.:

The effect of departures from lower critical temperature on the group postural behaviour of pigs. Anim. Prod., Edinburgh 33 (1981), 71-79

BRUMM, M.C.; REESE, D.E.:

Weaned Pig Management and Nutrition. Cooperative Extension, Institute of Agriculture and Natural Resources, University of Nebraska - Lincoln, G86-821-A, 1992

URL: http://www.ianr.unl.edu/pubs/Swine/g821.html (January 8th 2002)

ENGLISH, P.R.; SMITH, W.J.; MACLEAN, A.:

The sow - improving her efficiency. Farming Press, Suffolk, 1982, 141-165

GEERS, R.; GOEDSEELS, V.:

An improved system of temperature control in commercial pig houses: some effects on performance. Pig News and Inform., Wallingford 14 (1993) 2, 73N-75N

GEERS, R.; GOEDSEELS, V.; PARDUYNS, G.; VERCRUYSEE, G.:

The group postural behaviour of growing pigs in relation to air velocity, air and floor temperature. Appl. Anim. Behav. Sci., Amsterdam 16 (1986), 353-362

JACOBSON, L.D.; JOHNSTON, L.J.:

Save energy in the farrowing room with hovers. College of Agricultural, Food and Environmental Science. University of Minnesota Extension Service, FO-6513-GO, 1994,

KOVAČ, M.:

URL: http://www.extension.umn.edu/distribution/livestocksystems/DI6513.html (January 8th 2002)

Plodnost prašičev na kmetijah v letu 1996 (Pig fecundity on family-farms in year 1996). Sodobno kmetijstvo, Ljubljana 30 (1997) 7-8, 339-344

MAKKINK, C.A.; SCHRAMMA, J.W.:

Thermal requirements of the lactating sow. In: VERSTEGEN, M.W.A.; MOUGHAN, P.J.; RIST, M.: SCHRAMA, J.W. (Eds.) The lactating sow. Wageningen Pers, Wageningen, 1998, 271-283

Artgemäße Nutztierhaltung: Ein Schritt zum wesensgemäßen Umgang mit der Natur. Freies Geistesleben, Stuttgart, 1989, 45-73

SAS INSTITUTE INC.:

SAS/STAT User's Guide, Version 8, Volume 2, Cary, NC, 2000

VOGRIN-BRAČIČ, $M$.

Iskanje gospodarnih načinov ogrevanja gnezd za pujske (Searching for the economical methods of wrming up piglets' nests). Graduation Thesis, Department of Animal Science, University of Ljubljana, WEBER, R.: Domžale, Slovenia. 1998

Abferkelbuchten mit Kastenstand. Tänikon, FAT Berichte 318, 1987, 1-8

Received: 2002-02-18

Accepted: 2002-08-02

Authors' address

Prof. Dr. IVAN ŠTUHEC

Prof. MILENA KOVAČ, PhD

ŠPELA MALOVRH, BSc

Department of Animal Science, Biotechnical Faculty,

University of Ljubljana

Groblje 3

SI-1230 Domžale

Slovenia 